\title{
RECONSTRUÇÃO HISTÓRICA E IMAGINÁRIO DA GUERRA DO CONTESTADO: UMA BATALHA ENTRE ACONTECIMENTOS E SIGNIFICADOS
}

\author{
Celso Vianna Bezerra de Menezes \\ Professor de Antropologia do Departamento de Ciências Sociais/UEL \\ E-mail: macbel@sercomtel.com.br
}

\section{Resumo}

Este artigo discute as contribuições das ciências sociais brasileira sobre os fenômenos milenaristas e messiânicos. A reconstrução histórica de tais movimentos é baseada nas sugestões de Maria Isaura Pereira de Queiroz, para quem o imaginário do povo em geral não foi ainda suficientemente estudado, especialmente nos movimentos messiânicos. Partimos da noção de imaginário como concebida por Cornelius Castoriadis buscando uma outra leitura para os movimentos messiânicos no Brasil, mais especificamente dos eventos da chamada Guerra do Contestado. Propomos, portanto, um olhar sobre o fenômeno do messianismo capaz de ultrapassar algumas interpretações que só distinguem nestes movimentos características do "atraso". Ao demonstrar que imaginário está inextrincavelmente ligado a poder, poderemos restituir a estes sertanejos a condição de legítimos agentes históricos.

Palavras-chave: imaginário; messianismo; antropologia histórica; processo histórico.

m 1912, mês de outubro, um destacamento da Força Pública do

Paraná desloca-se de Curitiba para a pequena cidade de Palmas, no sul do estado, ponto de entrada da região àquela época disputada pelos estados de Santa Catarina e Paraná. O objetivo era atacar um grupo de "fanáticos" reunidos em torno de um homem, o monge José Maria, que, segundo se dizia, havia proclamado a "restauração da monarquia". Os "fanáticos", reunidos em torno do monge, reagiram ao 
ataque policial e assistiu-se a uma sangrenta luta entre sertanejos e soldados. Com esta batalha, teve início a "Guerra do Contestado"। que sacudiu aqueles sertões até 1916.

Segundo Maurício Vinhas de Queiroz (1981, p.82), "era certo que José Maria levava consigo a História de Carlos Magno e dos Doze Pares de França e nas horas de folga fazia a leitura de capítulos aos que o seguiam [...]. Nos sertões do Contestado, então, era comum a existência, mesmo longe das vilas, de uma velha edição dessa história. Um repórter observou que, entre os raros sertanejos alfabetizados, 'o livro predileto é uma maravilhosa História de Carlos Magno que entusiasma e alucina o seu espírito primitivo com aventuras extraordinárias de heróis invencíveis, homens que sozinhos atacam e derrotam exércitos aguerridos'. Ignora-se de que maneira José Maria comentava as façanhas dos cavaleiros da Távola Redonda, mas - como irão confirmar os episódios subseqüentes - essa literatura que exaltava a coragem pessoal, a luta contra os 'infiéis' e a fraternidade entre os campeões, marcaria diretamente os acontecimentos".

Independentemente do deslize do autor - a confusão entre Carlos Magno e os cavaleiros da Távola Redonda - interessante é que os sertanejos não somente conheciam a História de Carlos Magno, mas também a usaram como fonte para a organização da "irmandade cabocla"2 De acordo com Maurício Queiroz (1981, p.184-185), poderíamos

\footnotetext{
'Deu-se o nome de "Guerra do Contestado" ao movimento messiânico-milenarista ocorrido entre 1912 e 1916, na região serrana do atual estado de Santa Catarina. O nome provém do fato de a região ser disputada pelos estados de Santa Catarina e Paraná. A partir de 1889, com a instalação da República e as novas atribuições concedidas aos estados pela Constituição, a questão dos limites recrudesce em vista de interesses políticos e, sobretudo, fundiários. A disputa somente seria resolvida em 1916 junto com o final da Guerra do Contestado. Importante dizer, que apesar destas coincidências, a chamada Guerra do Contestado manteve com a questão dos limites uma ligação apenas incidental (MONTEIRO, 1977).

2 Os sertanejos do Contestado criaram inúmeros núcleos de "irmãos" na região considerada. Os núcleos, na verdade chamados de "redutos", foram formados porque acreditava-se que o "milênio" era iminente. Ele viria após a guerra que a "irmandade" moveria contra os infiéis, a "guerra santa", que teria início quando S. Sebastião descesse dos céus con seu "exército encantado", conforme teria anunciado o monge José Maria.
} 
questionar se os "Pares de França" surgiram por inspiração da História de Carles Magno, o livro mais lido nos sertões àquela época, ou se halsealram na organização das cavalhadas, festa dramática muitíssimo comum cm todo o interior do país e na qual freqüientemente os 'cristãos' se intitulavam pares ou cavalheiros da Távola Redonda". Mas, "seja como for, a nova instituição dos 'pares de França' nos redutos sofreu com o tempo modificações, não na forma, em seu tipo de organização, mas em seu perfil. Desde Caraguatá ${ }^{3}$, os pares de França constituíram sempre um piquete de elite, especializado no manejo de 'arma branca', pronto a intervir corpo-a-corpo no momento decisivo dos combates.[...] 'Os pares de França', como piquete permanente de elite, foram sempre integrados por vinte e quatro homens, incluído o seu comandante próprio, não o tamboreiro. Eram armados de garrucha e facão, que sempre constituíram, antes mesmo do movimento, 'as armas dos pobres' [...] Os pares de França se escolhiam entre os mais ágeis, os mais destros e os mais habilidosos no manejo do facão. Eram geralmente antigos praticantes do 'cortejo', uma espécie de esporte ou esgrima popular em que muitos sertanejos se exercitavam em todo momento de folga. O cortejo ou esgrima a facão requeria grande habilidade. 'Isto sim — diziam os caboclos — requeria coragem; não era 'máquina', como o revólver".

Curioso notar que os doze Pares de França das Histórias de Carlos Magno são 12 cavalheiros, pares entre si, ou seja, iguais, da mesma espécie, semelhantes. Segundo o Dicionário Petit Robert, par, no período feudal, "se dizia de vassalos que tinham o mesmo sangue com relação ao suzerano.” (ROBERT, 1978, p.1341). Na irmandade do Contestado, os doze pares são 24. Maria Isaura Pereira de Queiroz chega a afirmar que seriam 26. (QUEIROZ, 1993-1994, p.36). De qualquer modo, o termo "par" é concebido pelos sertanejos na sua acepção mais usual, a de dupla.

A História de Carlos Magno e dos Doze Pares de França são canções de gesta - descrições das façanhas dos guerreiros que

\footnotetext{
${ }^{3}$ Além de Caraguatá, havia o reduto de Taquaruçú, o mais antigo, o de Santa Maria, Bom Sossego, Tomazinho, Pinheiro, além de outros menores, como São Pedro, São Miguel e Pedras Brancas. Estima-se que a soma da população dos redutos chegaria a 20 mil habitantes.
} 
celebram os grandes feitos - escritas provavelmente entre os anos de 1098 e 1100, portanto quase três séculos após a morte de Carlos Magno, que se deu em 814. Segundo Otto Maria Carpeaux (1978, p.143), as canções sofrem de um grande anacronismo, pois o valor dessas produções reside na capacidade de representar uma nação, uma época. Com a nação francesa dos tempos posteriores, nação de patriotas cristãos, a Chanson de Roland (a mais famosa das gestas de Carlos Magno) pouco tem a ver. Roland e outras personagens revelam devoção cristã; porém esta não é motivo de sua ação. E patriotismo, no sentido moderno, a Idade Média não o conhece [...]. Os costumes feudais e as expressões religiosas não passam de um verniz. A Chanson de_Roland representa a época em que os franceses estavam mal cristianizados, e, por assim dizer, ainda não eram franceses. Eram francos. As canções pertenceriam à época de transição entre a barbaria germânica e a civilização francesa.

Carlos Magno foi um grande conquistador; ele quase dobrou o reino que tinha recebido de seu pai, Pepino. No entanto as canções "desenham" um outro homem: "As canções de gesta, o transfiguraram: Carlos Magno 'tem duzentos anos', sua barba é 'branca como flor em abril'; em outro lugar ele aparece 'todo de ferro, com a cabeça coberta com um capacete de ferro, luvas de ferro; ele tinha seu peito coberto de ferro e seus largos ombros de uma couraça de ferro. Ele foi, na realidade, um chefe de guerra previdente e rigoroso[...]"' (THORAVAL, 1978, p. 13).

Assim sendo, as Histórias de Carlos Magno, embora tenham origem histórica, tornaram-se criações lendárias que acabam por não dever quase nada aos acontecimentos históricos propriamente ditos. Como bem aponta Carpeaux (1978, p.139)., "a intervenção de Carlos Magno e dos seus 'pares' naquela luta (as lendas da guerra da Igreja Católica contra os infiéis, nos caminhos da romaria para Santiago de Compostela) introduziu extensa matéria de outra proveniência, lembranças de guerras feudais francesas, na própria França e em todo o mundo; tradições germânicas, pedaços do ciclo bretão e lembranças das Cruzadas contribuíram também para a elaboração de numerosas gestas em torno da geste de Charlemagne".

Estas criações lendárias são apropriadas pelos sertanejos do sul do Brasil; apropriadas e transformadas, como bem demonstra o 
fato, já apontado, do número dos “pares”. Mais ainda, são transformadas e postas junto a outros mitos e lendas. Como aponta Maurício Vinhas de Queiroz (1981, p.185), "os pares de França eram considerados 'apóstolos' e também 'nobres cavalheiros de São Sebastião'. Levavam consigo, dentro de patuás, orações que julgavam fortíssimas para fechar o corpo".

Assim, os pares de França tornam-se "cavalheiros de São Sebastião", mas quem foi D. Sebastião ${ }^{4}$ ? Maria Isaura Pereira de Queiroz (1993-1994, p.32) sintetiza:

Sem dúvida a história portuguesa teve papel preponderante, uma vez que os portugueses trouxeram consigo uma base lendária, as trovas do Bandarra, e uma figura heróica, D. Sebastião, base para o conhecimento do que sucedera na antiga metrópole. Por volta de 1535, um poeta popular português, Gonçalo Eanes Bandarra, escreveu em tom profético um conjunto de trovas, interpretando textos bíblicos, principalmente do Velho Testamento, em que profetizava a vinda de um enviado que salvaria o povo. Em 1578, a morte de D. Sebastião, rei de Portugal, na batalha infeliz de Alcácer-Kibir, fez com que, pelas leis sucessoriais, o país passasse para o domínio da Espanha. As trovas do Bandarra foram interpretadas como o anúncio do retorno do "moço rei", que arrancaria Portugal do jugo espanhol.

Os sertanejos do Contestado acreditavam que S. Sebastião fosse um guerreiro que viria auxiliar seus fiéis no combate desencadeado contra o Mal que avassalava o mundo; é aquilo que se convencionou chamar de sebastianismo nos movimentos messiânicos brasileiros. Ao messianismo deve-se acrescentar o milenarismo, conforme afirma Duglas Monteiro (1977, p.75), “[...] dos três movimentos que vêm sendo

\footnotetext{
${ }^{4} \mathrm{O}$ leitor poderia pensar que possa ter havido um erro na digitação, mas não é o caso. Há, de fato, um uso indistinto entre os personagens: São Sebastião e D. Sebastião. O primeiro, como sabemos, é o "santo guerreiro", santo muito popular entre os católicos do Brasil. O segundo é o rei português, o "encoberto", morto na África. "A semelhança entre as características do santo guerreiro e do Rei Encoberto leva a admitir que se trataria simplesmente de uma transmissão defeituosa do nome de uma época a outra e de uma região a outra" (QUEIROZ, 1993-1994, p. 40).
} 
estudados (Canudos, Juazeiro e Contestado), a Guerra do Contestado foi o único que tomou, inequivocamente, um caráter milenarista".

Adversários da República, os participantes da "irmandade" rebelde diziam-se monarquistas. Entretanto, a monarquia que aspirava, mais do que uma instituição política, era percebida como a realização de um "reino escatológico". Na tosca, mas expressiva indicação de um prisioneiro era uma "coisa do céu" - uma nova ordem que resultaria da união entre combatentes terrestres e o "exército encantado" de São Sebastião. Sob a chefia do santo desse nome - importante invocação no catolicismo rústico local - esperava-se que esse exército descesse dos céus trazendo consigo S. João Maria e S. José Maria, como passaram a ser tratados os antigos monges, além dos que haviam tombado nos combates".

Na verdade, de acordo com Jean Delumeau (1997, p. 18-19), as promessas milenaristas têm geralmente um caráter: elas anunciam uma mudança radical, uma salvação coletiva, iminente. Apelam ao agir humano e com frequiência profetizam um tempo de felicidade entre dois períodos de catástrofes. Tal é o caso do movimento do Contestado. Porém não devemos confundir milenarismo e messianismo. Ainda segundo Delumeau, no cristianismo, deve-se chamar de milenarismo a crença num reino terrestre vindouro de Cristo e de seus eleitos - reino este que deve durar mil anos, entendidos seja literalmente, seja simbolicamente. $\mathrm{O}$ advento do milênio foi concebido como devendo situar-se entre uma primeira ressurreição - a dos eleitos já mortos - e uma segunda -- a de todos os outros homens na hora de seu julgamento. [...]. Dois períodos de provações irão enquadrá-los. O primeiro verá o reino do Anticristo e as tribulações dos fiéis de Jesus que, com este, triunfarão das forças do mal e estabelecerão o reino de paz e de felicidade. O segundo, mais breve, verá uma nova liberação das forças demoníacas, que serão vencidas num último combate.

Até este momento, tentamos traçar um quadro daquilo que poderíamos chamar de imaginário central do movimento do Contestado ou, da "complexa construção ideológica da 'irmandade" do Contestado, como notou Duglas Monteiro (1977, p.84). Nosso objetivo é refletir se a noção de "imaginário social" pode tornar-se uma categoria operacional, permitindo-nos uma compreensão do movimento do Contestado, sob um ponto de vista diferente daquele que vem norteando os estudio- 
sos. Maria Isaura Pereira de Queiroz apontou a necessidade de pensar a questão do imaginário dos "movimentos messiânicos no Brasil" (QUEIROZ, 1993-94, p.36). Segundo a autora, as reivindicações socioeconômicas e políticas são formuladas através de um sistema de imagens provenientes da antiga metrópole. Este sistema alude a uma parte da religião que repentinamente passa a ser a base de outro tipo de organização socio-política. Portanto o romance de Carlos Magno e dos Doze Pares de França e a lenda do Rei Encoberto que se formava em torno de D. Sebastião, rei de Portugal, se entrosavam no grande complexo do catolicismo e, por meio dele, no cristianismo, como partes do santo combate entre cristãos e infiéis. A dimensão imaginária subitamente se corporificava solidificando-se na realidade e transformando-a. Dentro desta preocupação, faremos um breve apanhado dos estudos sobre o messianismo no Brasil, mais especificamente sobre o movimento do Contestado, para, então, introduzir na discussão a categoria de "imaginário social".

\section{História: entre acontecimentos e eventos}

Nos manuais mais divulgados da História do Brasil, os movimentos messiânicos pouco aparecem. Quando aparecem, vêm na forma de referências breves e quase sempre distorcidas. Tratando dos movimentos rebeldes em todo o mundo, o historiador Eric Hobsbawm (1987, p.12) observou que "nem podem eles ser simplesmente considerados como marginais ou sem importância, embora historiadores antigos assim tivessem procedido com freqüência, em parte devido à sua tendência racionalista e 'modernista', e em parte porque a inclinação e o caráter políticos desses movimentos são, muitas vezes, indeterminados, ambíguos ou mesmo ostensivamente 'conservadores', em parte ainda porque os historiadores, sendo em sua maioria homens cultos e urbanos, não fizeram, até bem pouco tempo, um esforço suficiente para compreender pessoas que não se assemelham a eles".

No Brasil, os movimentos messiânicos eram considerados como primitivos ou arcaicos; sempre foram interpretados como fruto do "fanatismo" entranhado no espírito das massas "atrasadas" que povoam 
o interior do país. "Afinal, pensavam os intelectuais contemporâneos, só mesmo o isolamento dessas massas poderia explicar seu comportamento divergente em relação aos padrões civilizados da sociedade litorânea, e sua relativa imunidade frente às ondas de progresso que aportavam em nossas costas no alvorecer do século XX.” (MENDES JR.; MARANHÃO, 1981, p.168).

Percebe-se claramente como tais movimentos tornaram-se, em parte pelo menos, uma "criação" da sociedade brasikeira corroborada pelos intelectuais. No caso específico de Canudos, não seria incorreto dizer que o próprio Os Sertões de Euclides da Cunha faz parte daquilo que chamamos de "Canudos". Façamos uma longa citação deste clássico:

Esta justaposição histórica calca-se sobre três séculos. Mas é exata, completa, sem dobras. Imóvel o tempo sobre a rústica sociedade sertaneja, despeada do movimento geral da evolução humana, ela respira ainda na mesma atmosfera moral dos iluminados que encalçavam, doudos, o Miguelinho ou o Bandarra. Nem lhe falta, para completar o símile, o misticismo político do sebastianismo. Extinto em Portugal, ele persiste todo, hoje, de modo singularmente impressionador, nos sertões do norte.

Insistamos sobre esta verdade: a guerra de Canudos foi um refluxo em nossa história.

Vivendo quatrocentos anos no litoral vastíssimo, em que pelejam reflexos da vida civilizada, tivemos de improviso, como herança inesperada, a República. Ascendemos, de chôfre, arrebatados na caudal dos ideais modernos, deixando na penumbra secular em que jazem, no âmago do país, um terço de nossa gente. [...] tornamos, revolucionariamente, fugindo ao transigir mais ligeiro com as exigências da nossa própria nacionalidade, mais fundo o contraste entre o nosso modo de viver e o daqueles rudes patrícios mais estrangeiros nesta terra do que os imigrantes da Europa. Porque não no-los separa um mar, separam-no-los três séculos[...] (CUNHA, 1968, p.105,153).

Foi somente a partir dos finais da década do 50 que esta postura passou a ser criticada. Para o caso específico do movimento do Contestado, ela se inicia com os estudos de Maria Isaura Pereira de Queiroz. Façamos um breve resumo das principais obras analíticas sobre 
este movimento: além das de Maria Isaura Pereira de Queiroz (1957, 1977, 1972, 1993-1994), a de Maurício Vinhas de Queiroz (1981) e as de Duglas Teixeira Monteiro (1974, 1977).

O trabalho de Maurício Vinhas de Queiroz (1981, p.252-253) é de grande fôlego, fruto de uma criteriosa pesquisa documental e de campo. Relata minuciosamente os intricados fatos ligados ao decorrer das lutas nos anos compreendidos entre 1912-1916. Seu argumento central é de que o Contestado foi decorrência de uma crise estrutural. A Guerra Santa evidenciou uma crise na concepção do mundo; por este fato, foram postas em jogo as próprias bases estruturais da totalidade social, tal como podia ser percebida pelos sertanejos. A Guerra Santa foi o epicentro de um abalo de grande envergadura e nela os fatores conjunturais desempenharam o papel de forças desencadeantes, gatilhos. Como consequiência destes argumentos, o autor conclui que o "messianismo é uma revolta alienada". Tais movimentos de natureza religiosa "levam sempre a um alheamento, a um desligamento do corpo social, e à instrumentação, fora dele e oposta a ele, de uma nova comunidade que confia na transfiguração supranaturalística do mundo." E, principalmente, há um sentido trágico nos surtos messiânicos: "a coletividade que se revolta não tem possibilidades objetivas de vitória, dado que não pode - por causas muito concretas - viver independentemente ou estabelecer novas relações entre os homens no processo econômico de produção rotineira de bens."

Duglas Monteiro também parte de uma visão que entende o movimento como conseqüência de uma crise estrutural, mas os desdobramentos serão bem distintos dos vistos na obra de Maurício Vinhas de Queiroz. O objetivo dele foi "analisar" o comportamento social de uma comunidade humana que, enfrentando uma crise global, recolocou, dentro dos limites que the eram dados, os problemas fundamentais de sua existência como grupo. "Ao fazê-lo, elaborou um universo mítico, adotando as condutas ritualizadas correspondentes. O objetivo fundamental da investigação é este. Em certo sentido, a longa parte dedicada ao estudo das condições que levaram o grupo para esse caminho (denominada 'o desencantamento do mundo') é uma preparação para a parte subsequiente, onde se procura entender a construção de uma comunidade que vive, organiza-se e luta contra 
seus adversários dentro de um espaço e de um tempo míticos" (MONTEIRO, 1974, p.10-11). Este autor inicia seu trabalho, portanto, analisando as bases históricas e estruturais deste "desencantamento do mundo", quando enfatiza as alterações fundamentais sofridas pelo mandonismo local em virtude das "transformações pelas quais passou o país no plano político e administrativo com o advento da República" (p.209); os novos conteúdos da violência em razão de novas formas de produção e de relações de trabalho; o significado da crise no sistema de compadrio; o relacionamento entre frades e monges, com suas ambigüidades e definição de campos. Dando sequiência, o autor analisou o "reencantamento do mundo", quando levanta os elementos do universo ideológico dos rebeldes. Ao discutir as motivações da adesão dos caboclos ao movimento rebelde, afirma que a "conclusão a que se chegou foi a de que a variedade de motivos, de disposições subjetivas e de condições objetivas que constituíram os fatores originais da opção tomada pelos que aderiram, acabou por concentrar-se dentro de uma linha de natureza eminentemente religiosa" (p.214).

Duglas Monteiro $(1974$, p.12-15) trouxe uma contribuição importante não só para a compreensão da Guerra do Contestado, mas também de outros movimentos messiânicos brasileiros. Ele parte de uma constatação: os movimentos messiânicos são analisados, na maioria das vezes, de uma perspectiva que implica reducionismo. Esse reducionismo parte de alguns pressupostos: de um lado, uma posição etnocêntrica que enxerga nos "fanatismos" nada mais que a manifestação de um "atraso" das populações do sertão, como as afirmações de Euclides da Cunha bem o demonstram; por outro, uma atitude metodológica presente numa tradição racionalista, na qual religião é equacionada com ignorância e, ato seguinte, tomada como mero epifenômeno a ser desconsiderado, ela é uma capa que esconde o que seria o essencial. $\mathrm{O}$ autor cita uma frase que deveria ser considerada como subtítulo de seu trabalho: "nos redutos tinha mistério". Partindo dela, ele afirma: "que fica claro que a crise torna-se compreensível através da resposta que lhe é dada. É através dessa resposta que as contradições da ordem pretérita e o sentido de suas instituições tornamse inteligíveis. Por isto, em casos como estes, um acesso privilegiado para a interpretação é dado pelo universo de significados elaborado 
pelos que a enfrentam". A contribuição deste autor, portanto, foi feita a partir de um deslocamento em que ele procurou captar o significado que os próprios agentes atribuíram às suas ações. A categoria do "mistério" não apenas fornece os sentidos, mas é realizadora de história, isto é, de ações concretas visando modificar situações reais (POMPA, 1998, p.187).

Deixamos por último a extensa obra de Maria Isaura Pereira de Queiroz $(1957,1972,1977)$ porque foi ela quem inaugurou a discussão dos movimentos messiânicos com uma abordagem sociológica e, num de seus últimos trabalhos a respeito do tema, procurou trabalhar o conceito de imaginário e os movimentos messiânicos no Brasil. Bem resumidamente abordaremos os argumentos centrais nas obras clássicas da autora.

Longe de pensar a eclosão do movimento messiânico como uma crise estrutural, a autora o analisa sob o ponto de vista da continuidade, com relação à ordem passada, ou seja, ela acentua a conservação das hierarquias tradicionais no quadro santo ${ }^{5}$. Dentro desta concepção, ela vai concluir que os movimentos messiânicos possuem um teor restaurador e/ou conservador, sendo um dos fatores da continuidade do sistema social. O movimento é entendido como fruto das tensões criadas pelas anomias. Portanto, ela descarta as razões de um possível "choque cultural" entre a comunidade sertaneja rústica e a sociedade ampla e moderna. Assim, o movimento advém pelo agravamento de uma condição de desorganização social que é endêmica no sertão e tal agravamento é decorrência de condições e fatores conjunturais.

Vejamos, então, como estas concepções da autora se articulam com a noção de imaginário. Michele Perrot apud Maria Isaura Pereira de Queiroz (1993-1994), afirma que o imaginário dos povos tem como fontes a religião, a ciência e a história. No caso do movimento messiânico, lança-se mão principalmente da história e da religião: as imagens de D. Sebastião e dos Doze Pares de França permanecem na

\footnotetext{
5"Quadro santo" era uma praça retangular onde se situava uma igreja. Em cada um dos quatro ângulos, um grande cruzeiro assinalava os pontos significativos de seu perímetro, demarcando um recinto cuja diferenciação com respeito ao que estava fora era, periodicamente, reforçada por circuitos processionais (MONTEIRO, 1974 , p. 128).
} 
consciência, no íntimo da população sertaneja. "Religião e história são componentes básicos dos movimentos messiânicos aqui estudados; 0 imaginário que a eles acompanha pertence ao mesmo tempo ao cristianismo e ao passado. Todavia, para que passe a existir, trazendo 0 milagre para a vida cotidiana, foi necessário todo um conjunto de circunstâncias socioeconômicas e políticas, claramente encontradas em Canudos e Contestado" (QUEIROZ, 1993-94, p.37-40, grifo nosso). A idéia central, portanto, está em perguntar quais as razões que possibilitavam implantar o imaginário, latente durante tanto tempo, na realidade. Assim, com as palavras da autora, nos movimentos messiânicos a "construção de uma sociedade 'outra' significa que a coletividade não se contenta mais com crenças; torna-se fundamental para ela passá-las para a prática, o que implica a criação de uma maneira de viver considerada diversa da anterior." Portanto, na relação imaginário e história, os termos são cambiáveis, são condição e/ou produto um do outro. Enfim, a história cria o imaginário e este, como crenças cristalizadas na memória, criaria os fatos históricos sob determinadas circunstâncias. A autora conclui: "A crença em D. Sebastião foi uma criação da história, intervindo no imaginário coletivo dos brasileiros; por sua vez, esta, 'irriga' a história, criando um novo fato histórico, o movimento messiânico; mas foi principalmente a decorrência de uma situação sóciopolítico e econômica específica que tornou ativa a crença e, por sua vez, "criou' um novo fato histórico".

\section{Reconstrução histórica: entre textos e con-textos}

A revista Veja publicou uma longa reportagem no centenário do fim da Guerra de Canudos. O repórter Renato Pompeu de Toledo, autor do artigo, observa um fato crucial de Canudos, que, supomos, se repete no Contestado. Ele afirma :

No dia 18 de julho de 1897, o jornal O País, do Rio de Janeiro um dos principais da então capital federal, dirigido pelo eminente Quintino Bocaiúva - , publicou um artigo em que se lia, sob o título 'o Monstro de Canudos'.

O Monstro, ao longe, nas profundezas do sertão misterioso, 
cscinciara als guclrans insaciáveis, pedindo mais gente, mais parte de coraçoes republicanos, um farnel mais opulento de heróis e a fera ir-sé-á abastecendo e devorando até que num assomo de raiva, ao sentir a falta de ucharia, desse abastecimento de corpos, desgrenhe a juba e com um arranque de sua pata monstruosa queira esmagar a pátria, em crepe pela morte dos seus filhos mais amados, pelo massacre do seu exército glorioso!

Trata-se de um animal fantástico, como observa professora Walnice Galvão, autora de No Calor da Hora, livro que reúne as coberturas da imprensa da guerra. Tem guelras de peixe e juba de leão. Custa crer que se levasse a sério que o arraial miserável do Conselheiro, situado um pouco para lá do fim do mundo, representasse tal ameaça à pátria. $\mathrm{E}$, no entanto, pelo que se lia nas páginas arrebatadas dos jornais, frementes de patriotismo, levava-se sim (TOLEDO, 1997, p.84).

Esta citação chama a atenção para um fato "crucial", que é a "comoção" que tomou conta do país à época de Canudos e que vemos se repetir, quando da Guerra do Contestado. A imagem do monstro foi realmente levada a sério por toda a opinião pública nacional. Desse modo, pouco interessa se o "monstro" existia, ou não. Como afirma Cornelius Castoriadis (1982, p.170), o imaginário social é mais real do que o "real". O que interessa é, portanto, que as pessoas acreditem na existência do monstro. O fenômeno da "eficácia simbólica", como descreve Lévi-Strauss (1975, p.233) quando trata do xamanismo. Enfim, aquilo a que se assiste é uma "construção", uma construção imaginária. O mesmo fenômeno é detectado por Edward Said (1990, p.17) em seu estudo sobre o orientalismo: "Comecei com a suposição de que o Oriente não é um fato inerte da natureza. [...]. Portanto, assim como o próprio Ocidente, o Oriente é uma idéia que tem uma história e uma tradição de pensamento, imagística e vocabulário que lhe deram realidade e presença no e para o Ocidente. As duas entidades geográficas, desse modo, apóiam e, em certa medida, refletem uma a outra." Porém, como aponta Said, não são só essencialmente idéias, pois a relação entre o Ocidente e o Oriente é uma relação de poder, de dominação, de graus variados de uma complexa hegemonia.

De outro lado, é o que se nota na tão propalada discussão a respeito do "choque cultural" entre a cultura rústica do sertanejo e a 
cultura do litoral. Euclides da Cunha, no trecho que citamos, aponta a diferença de "três séculos que separariam as duas culturas". Para a parcela "moderna" da sociedade brasileira trata-se da idéia de que a passagem do tempo tem efeito cumulativo. "Essa crença no poder concedido pelo tempo linear progressivo tem implicações para a teoria política: dela deriva-se a idéia de que é natural que os Estados nacionais se tornem maiores e as civilizações se tornem melhores. Segundo a doutrina colonialista, os maiores e mais poderosos são os mais avançados, não apenas em tecnologia, mas também na sequiência temporal; assim, no discurso político, eles têm o direito moral — por serem temporalmente mais avançados - de ter poder sobre os pequenos, os que por definição fazem parte do passado atrasado. Os menores, por não terem aproveitado o acúmulo do tempo, vivem em tempos passados" (OVERING, 1995, p.131-132).

Portanto não se trataria, como quer Maria Isaura Pereira de Queiroz (1993-1994, p.37), de opor a realidade ao imaginário, especular, imagem de algo (CASTORIADIS, 1982, p.13). Como afirma Borges (1985, p.449), no seu conto Pierre Menard, Autor do Quixote, "Menard, contemporâneo de William James, não define a história como uma indagação da realidade, mas como sua origem. A verdade histórica, para ele, não é o que aconteceu, é o que julgamos que aconteceu”. O problema, portanto, é de uma certa concepção de imaginário na análise do social-histórico.

Castoriadis (1982, p.154-175) aponta para a dificuldade que a antropologia e a psicanálise encontram em diferenciar os registros e a ação do simbólico e do imaginário, pois, "as significações imaginárias sociais - pelo menos as que são verdadeiramente últimas - não 'denotam' nada, e 'conotam' mais ou menos tudo; e é por isso que elas são tão freqüientemente confundidas com seus símbolos, não somente pelos povos que as utilizam, mas pelos cientistas que as analisam e que chegam, por isso, a considerar que seus significantes se significam por si mesmos (uma vez que não remetem a nenhum real, nenhum racional que pudéssemos 'designar'), e a atribuir a esses significantes como tais, ao simbolismo tomado em si mesmo, um papel e uma eficácia infinitamente superiores às que certamente possuem." Acompanhemos, resumidamente, a concepção de Castoriadis sobre o simbólico e o 
imaginário. Segundo ele, todo símbolo ou simbolismo tem um componente imaginário. "O imaginário deve utilizar o simbólico, não somente para 'se exprimir', o que é óbvio, mas para 'existir', para passar do virtual a qualquer coisa a mais. $\mathrm{O}$ delírio mais elaborado bem como a fantasia mais secreta e mais vaga são feitos de 'imagens', mas estas 'imagens' lá estão como representando outra coisa; possuem, portanto, uma função simbólica, mas também, inversamente, o simbolismo pressupõe a capacidade imaginária, pois pressupõe a capacidade de ver em uma coisa o que ela não é, de vê-la diferente do que é. Entretanto, à medida que o imaginário se reduz finalmente à faculdade originária de pôr ou de dar-se, sob a forma de representação, uma coisa e uma relação que não 'são' (que não são dadas na percepção ou nunca o foram), falaremos de um imaginário último ou radical, como raiz comum do imaginário efetivo e do simbólico. É finalmente a capacidade elementar e irredutível de evocar uma imagem". Temos, assim, a noção central de imaginário radical, que se distingue do imaginário efetivo, pois que este se caracteriza pelo vínculo rígido entre significante e significado, o símbolo e a coisa. O imaginário é, portanto, algo "inventado", "quer se trate de uma invenção 'absoluta' [...], ou de um deslizamento, de um deslocamento de sentido, onde símbolos já disponíveis são investidos de outras significações que não suas significações 'normais' ou 'canônicas'".

Castoriades (1982, p.14) critica a visão funcionalista e afirma o primado do simbólico do social-histórico. Assim, considera que "tudo o que se nos apresenta, no mundo social-histórico, está indissociavelmente entrelaçado com o simbólico"; os inumeráveis produtos materiais não são símbolos, mas são impossíveis fora de uma rede simbólica. Enfim, o imaginário é criação incessante e essencialmente indeterminada; daí sua visão da história que é "essencialmente poiésis, e não poesia imitativa, mas criação e gênese ontológica no e pelo fazer e o representar/dizer dos homens".

A concepção de imaginário de Castoriadis (1982, p.416) conduz a um componente político muito importante. Usemos suas palavras ainda uma vez: "Enquanto instituinte e enquanto instituída, a sociedade é intrinsecamente história — ou seja, auto-alteração. A sociedade instituída não se opõe à sociedade instituinte como um produto morto 
a uma atividade que o originou; ela representa a fixidez/estabilidade relativa e transitória das formas-figuras instituídas em e pelas quais somente o imaginário radical pode ser e se fazer ser como socialhistórico. A auto-alteração perpétua da sociedade é seu próprio ser. Cada sociedade faz ser também seu próprio modo de auto-alteração, que podemos também denominar sua temporalidade — isto é, se faz ser também 'como' modo de ser."

Apoiados nesta concepção de imaginário e vendo no simbólico a lei fundamental de que ele é essencialmente diacrítico, ou seja, ele age por diferença, é que podemos pensar o movimento do Contestado como o próprio poder político em ação, no qual o domínio do imaginário e do simbólico é um importante lugar estratégico. Como diz Baczko (1954, p.12), "as ciências humanas mostraram porém que, contrariamente aos slogans que pediam a imaginação no poder (no maio de 68, na França), "esta sempre tinha estado no poder"".

Acreditamos que a ciência antropológica tem uma importante contribuição a dar para a compreensão dos fenômenos religiosos chamados "rústicos". O deslocamento do olhar preconizado por esta ciência permite perceber que a racionalidade esclarecida e o utilitarismo são maneiras pelas quais a sociedade ocidental interpreta o mundo; são, portanto, explicações de uma determinada forma cultural. O processo histórico é, assim, culturalmente significado. Sahlins (1995, p.11) afirma que ordens culturais diversas têm modos próprios de produção histórica: culturas diferentes, historicidades diferentes. Culturas diferentes reagem de forma diferente a um evento e fazem dialogar o contexto imediato com estruturas culturais anteriores, ou seja, repõem estruturas passadas na orquestração do presente. Romper com a visão dicotômica que opõe história e estrutura permitirá restituir aos sertanejos da Guerra do Contestado a condição de legítimos agentes históricos. Ou seja, analisar o Contestado, ou qualquer outro movimento sócio-religioso, como uma prática da estrutura, a estrutura como história (SAHLINS, 1995, p.181), a fim de perceber as significações imaginárias que, embora expressas nos símbolos, vão além deles. A proposta deste artigo seria repensar a dicotomia presente em certas concepções de imaginário que o tratam como parte da realidade social, mas o tomam como momento distinto do fazer histórico. 
Enlim. nĩo se trata de procurar, neste movimento, por detrás das construçōes imaginárias, uma realidade despojada das "máscaras dos agenles". pois que chegaremos tão somente a uma construção. Essa é a visão de Duglas Monteiro, o qual, nas suas conclusões, afirma que "procurou evidenciar que o significado social assumido pela lenda de Carlos Magno transcende os quadros de uma referência 'histórica' disponível para o sertanejo à falta de marcos mais sólidos. Antes que uma simples expressão de carência, esse elemento da subcultura rústica alcança a dimensão de instrumento na redefinição da auto-imagem de um grupo humano em crise [...] Pela sublimação dos elementos 'positivos', das associações morais e da 'face boa' da vida pretérita, o passado é mitificado e a continuidade entre o mundo de Roldão e o dos 'belos cavaleiros de S. Sebastião' se estabelece. A lenda não é mera inspiração. Reempregando a expressão de P. Ricoeur, dir-se-ia que, através dela, efetua-se a "verificação do mito pela vida"' (MONTEIRO, 1974). Não foi Riobaldo, o do Rosa, quem, há muito tempo, se perguntava: "Como é que se pode gostar do verdadeiro no falso?".

\section{Referências Bibliográficas}

BACZKO, Bronislaw. Les Imaginaires Sociaux. Paris: Payot, 1954.

BORGES, Jorge Luis. Pierre Menard, autor del Quixote. Buenos Aires: Emecé Editores, 1985. (Obras Completas)

CARPEAUX, Otto Maria. História da Literatura Ocidental. Rio de Janeiro: Editorial Alhambra, 1978. v.1.

CASTORIADIS, Cornelius. A Instituição imaginária da sociedade. Rio de Janeiro: Paz e Terra, 1982.

CUNHA, Euclides da. Os Sertôes. Rio de Janeiro: Francisco Alves, 1968.

DELUMEAU, Jean. Mil Anos de Felicidade: uma história do paraíso. São Paulo: Cia. Das Letras, 1997.

HOBSBAWM, E. J. Rebeldes Primitivos. Rio de Janeiro: Zahar, 1978.

LE GOFF, J. et al. Histoire et Imaginaire. Paris: Radio France/Éditions Poiesis, 1986. 
LÉVI-STRAUSS, Claude. A eficácia simbólica. In: Antropologia Estrutural. Rio de Janeiro: Tempo Brasileiro, 1975.

MENDES Jr., Antonio; MARANHÃO, Ricardo (Orgs.). República Velha. In: . Brasil História. Texto e Consulta. São Paulo: Brasiliense, 1981. v.3.

MONTEIRO, Duglas Teixeira. Os Errantes do Novo Século. São Paulo: Duas Cidades, 1974.

- Um Confronto entre Juazeiro, Canudos e Contestado. In: HISTÓRIA Geral da Civilização Brasileira. Rio de Janeiro: Difel, 1977. t.3, v.2.

OVERING, Joana. O mito como História: um problema de tempo, realidade e outras questões. Revista Mana, Rio de Janeiro, v.1, n.1, p.107-140, out., 1995.

POMPA, Cristina. A Construção do Fim do Mundo. Revista de Antropologia, São Paulo, v.41, n.1, p.177-212, 1998.

QUEIROZ, Maria Isaura Pereira de. La "Guerre Sainté" au Brésil: Le Mouvement Messianique du "Contestado". São Paulo: USP, 1957.

O Messianismo no Brasil e no Mundo. São Paulo: Alfa-Ômega, 1977.

Images Messianiques du Brésil. México: Sondeos, 1972.

. D. Sebastião no Brasil. Revista USP. Dossiê Canudos. São Paulo, v.20, p.28-41, Dez/Jan/Fev, 1993-1994.

QUEIROZ, Maurício Vinhas de. Messianismo e Conflito Social. São Paulo: Ática, 1981.

ROBERT, Paul. Le Petit Robert. Paris: Société du Nouveau Littré, 1978.

SAHLINS, Marshall. Historical Metaphors and Mythical Realities. Michigan: The University of Michigan Press, 1995.

SAID, Eduard W. Ocidentalismo: Oriente como invenção do Ocidente. São Paulo: Cia. Das Letras, 1990.

THORAVAL, Jean et al. Les Grandes Étapes de la Civilisation Française. Paris: Bordas, 1978.

TOLEDO, Renato Pompeu de. O Legado de Conselheiro. Veja, São Paulo, v.30, n.35, p.64-87, set. 1997. 


\section{Abstract}

This article discusses the brazilian social sciences contributions to milenarist and messianic movements. The historical reconstruction of these phenomenons is based in the suggestions of Maria Isaura Pereira de Queiroz, to whom the imaginary of the people was not enoughly studied, especially into the messianic movements. We take the notion of imaginary as conceived by Cornelius Castoriadis, seeking to achieve another reading to the brazilian messianic movements, more specifically to the events of the so called Guerra do Contestado. Therefore we propose a new point about the messianic phenomenon, in order to go beyond sone interpretations which only distinguish at these movements the caractheristics of "retardments". Demonstrating that imaginary is inextricably connected to power, we may restitute to these sertanejos their legitime historical agents condition.

Key-words: imaginary; historical anthropology; messianism; historical process. 